\title{
Implications of a Carbonate Ion Effect on Shell Carbon and Oxygen Isotopes for Glacial Ocean Conditions
}

\author{
D. W. Lea ${ }^{1 *}$ J. Bijma ${ }^{2}$, H. J. Spero ${ }^{3}$ and D. Archer ${ }^{4}$ \\ ${ }^{1}$ Department of Geological Sciences and the Marine Science Institute, University of \\ California, Santa Barbara, California 93106, U.S.A. \\ ${ }^{2}$ Universität Bremen, Fachbereich Geowissenschaften, Postfach 3304 40, \\ D-28334 Bremen, Germany \\ ${ }^{3}$ Department of Geology, University of California, Davis, California 95616, U.S.A. \\ ${ }^{4}$ Department of Geophysical Sciences, University of Chicago, 5734 S. Ellis Ave, Chicago, \\ IL, 60615, U.S.A. \\ *corresponding author (e-mail): lea@magic.geol.ucsb.edu
}

\begin{abstract}
Experimental work demonstrates that the carbon and oxygen isotopic composition of planktic foraminifera shells is directly influenced by the carbonate equilibrium state of seawater (Spero et al. 1997). Because the $\mathrm{pCO}_{2}$ of the sea surface and the atmosphere must be in approximate equilibrium, the glacial drop in atmospheric carbon dioxide recorded in ice cores must have been accompanied by an increase in surface water carbonate ion concentration. Calculations indicate that increased carbonate ion during glacial episodes can account for much or all of the observed negative $\delta^{13} \mathrm{C}$ shift in planktic shells. This discovery provides a novel explanation for the large, negative swings in planktic $\delta^{13} \mathrm{C}$ observed in the glacial sections of Southern Ocean cores. It also presents an alternative hypothesis to the terrestrial biosphere-to-ocean transfer of carbon that is generally accepted as an explanation for lower glacial shell $\delta^{13} \mathrm{C}$ values (Shackleton 1977). Our analysis suggests that shell isotopic composition can provide a constraint on the extent of oceanic carbonate ion changes, potentially narrowing explanations for the glacial $\mathrm{pCO}_{2}$ drawdown. Correcting for the influence of the carbonate ion effect on shell $\delta^{18} \mathrm{O}$ lowers glacial tropical sea surface temperature (SST) estimates by up to $1^{\circ} \mathrm{C}$, which brings oxygen isotope paleotemperatures closer to those marine SST proxies (e.g. coral $\mathrm{Sr} / \mathrm{Ca}$ ) and those terrestrial indicators (e.g. snow-line and ice core $\left.\delta^{18} \mathrm{O}\right)$ that suggest more intense tropical cooling at the last glacial maximum (Guilderson et al. 1994; Thompson et al. 1995).
\end{abstract}

\section{Introduction}

Shackleton first pointed out that benthic shells from glacial sections of deep-sea cores are characterized by lower ${ }^{13} \mathrm{C} /{ }^{12} \mathrm{C}$ values (Shackleton 1977). $\mathrm{He}$ interpreted this change as a consequence of the transfer during glacial episodes of organic carbon depleted in ${ }^{13} \mathrm{C}$ from the terrestrial biosphere to the oceanic dissolved inorganic carbon (DIC) pool. Subsequent studies revealed that downcore changes in benthic $\delta^{13} \mathrm{C}$ can also be ascribed to changes in other factors, including shifts in the abyssal circulation (Boyle and Keigwin 1982; Curry and Lohmann 1982; Shackleton et al. 1983b), air- sea exchange (Charles et al. 1993) and physiological and/or environmental artifacts (McCorkle et al. 1990; Mackensen et al. 1993). Although the combined influence of these factors complicates the interpretation of benthic $\delta^{13} \mathrm{C}$ records, comparison of records from different basins makes it possible to extract the mean ocean shift in $\delta^{13} \mathrm{C}$ (Boyle and Keigwin 1985, 1986).

Recent compilations suggest that mean ocean $\delta^{13} \mathrm{C}$ was $0.32 \%$ more negative during the Last Glacial Maximum (LGM), 20 ka (Curry et al. 1988; Duplessy et al. 1988; Boyle 1992). If this shift is entirely attributed to a transfer of carbon from the 
terrestrial biosphere to the oceans, it is consistent with an addition to the glacial oceans of $450 \mathrm{Gt}$ terrestrial carbon with a $\delta^{13} \mathrm{C}$ of $-25 \%$, or about $21 \%$ of the present biospheric carbon reservoir (including dead soil organic matter $)\left(1 \mathrm{Gt}=10^{15} \mathrm{~g} \mathrm{C}\right)$. Pollen databases from the LGM appear to be consistent with a substantially larger reduction of the terrestrial biosphere $(750$ - $1350 \mathrm{Gt})$, although there is considerable uncertainty associated with estimating terrestrial carbon mass and in predicting how efficiently carbon is transferred to the ocean during glaciations (Crowley 1995). An additional complication is that some of the glacial carbon addition might have come from the erosion of continental shelves exposed by lower sea level (Broecker 1982b).

Planktic foraminiferal $\delta^{13} \mathrm{C}$ records are complicated by isotopic offsets between species, variations in $\delta^{13} \mathrm{C}$ with shell size, and disequilibrium effects attributable to the presence of symbiotic algae (Berger et al. 1978; Spero and Williams 1988; Oppo and Fairbanks 1989; Spero and Lea 1996). Records of Globigerinoides sacculifer, the principal species used for tropical reconstructions, reveal that shells deposited in LGM sections average only about $0.2 \%$ more negative in $\delta^{13} \mathrm{C}$ than their Holocene counterparts (Curry and Crowley 1987; Oppo and Fairbanks 1989). In addition, low latitude planktic $\delta^{13} \mathrm{C}$ records are characterized by the most negative $\delta^{13} \mathrm{C}$ values occurring on the glacial terminations rather than during the LGM. Despite the complexity of these records, an increase in plankticbenthic $\delta^{13} \mathrm{C}$ differences in the glacial sections of tropical cores has been cited as evidence of a stronger biological pump during glacial periods (Shackleton et al. 1983a; Shackleton and Pisias 1985; Curry and Crowley 1987; Shackleton et al. 1992). The largest shift in planktic $\delta^{13} \mathrm{C}$ is observed in cores from the Southern Ocean, where shells taken from the glacial sections are typically $1 \%$ more negative than interglacials (Labeyrie and Duplessy 1985; Charles and Fairbanks 1990; Charles et al. 1996). Neither the magnitude nor direction of the Southern Ocean $\delta^{13} \mathrm{C}$ shifts have been adequately explained because the large nutrient changes implied by the shifts are not supported by coincident changes in other proxies (Boyle 1988; Lea 1995), are opposite to those ex- pected from a strengthened biological pump (Broecker 1982a), and are greater than could be reasonably inferred from changes in gas exchange (Charles et al. 1993).

\section{Influence of Seawater Carbonate Ion Concentration on Foraminiferal Isotopes}

Culturing experiments demonstrate that the $\delta^{13} \mathrm{C}$ and $\delta^{18} \mathrm{O}$ composition of planktic foraminifera shells responds to changes in seawater carbonate ion concentration (Spero et al. 1997) (Bijma et al. this volume). The average response of shell $\delta^{13} \mathrm{C}$ in the growth experiments is $-0.006 \%$ for Orbulina universa and -0.012\%o for Globigerina bulloides per $\mu \mathrm{mol} / \mathrm{kg}$ increase in seawater carbonate ion. The response for shell $\delta^{18} \mathrm{O}$ is -0.002 and $-0.004 \%$ per $\mu \mathrm{mol} / \mathrm{kg}$ carbonate ion for $O$. univers $a$ and $G$. bulloides, respectively. Carbonate ion concentration is utilized as the independent variable because, unlike $\mathrm{pH}$, under different experimental conditions isotopic deviations are a linear function of carbonate ion. However, because $\mathrm{pH}$ and carbonate ion vary together in seawater, we do not have proof that carbonate ion concentration is the controlling variable. The isotopic response of the shells to changes in carbonate ion concentration presumably reflects a kinetic response during calcite precipitation (Spero et al. 1997). Newer results reveal a similar affect for two tropical, surface-dwelling species, Globigerinoides ruber and Gs. sacculifer (Bijma et al. 1998).

Ice core records indicate that atmospheric $\mathrm{pCO}_{2}$ levels dropped to about $200 \mathrm{ppmV}$ during the LGM, although the cause of the reduction remains unexplained (Barnola et al. 1987; Jouzel et al. 1993). Glacial reconstructions demonstrate that temperature and salinity changes alone cannot account for more than a small fraction of this $\mathrm{pCO}_{2}$ reduction (Broecker 1982a; Broecker and Peng 1993). Because the surface ocean must on average have the same $\mathrm{pCO}_{2}$ as the atmosphere and because sea surface temperatures did not drop sufficiently to cause the observed $\mathrm{pCO}_{2}$ reduction (Broecker and Peng 1993), lower glacial $\mathrm{pCO}_{2}$ levels must reflect an increase in average sea surface carbonate ion, or more specifically an increase in the ratio of alkalinity (excess base) to $\mathrm{CO}_{2}$. Based on the results 
of culturing experiments, this increase in sea surface carbonate ion is expected to influence the isotopic composition of planktic foraminifera.

We have calculated surface water carbonate ion anomalies at temperatures of $10^{\circ} \mathrm{C}$ and $25^{\circ} \mathrm{C}$ for two hypotheses put forth to explain the glacial decrease in $\mathrm{pCO}_{2}$ : a stronger biological pump, and a rise in whole ocean $\mathrm{pH}$ driven by changes in $\mathrm{CaCO}_{3}$ cycling (Berger 1982; Broecker 1982b; Archer and Maier-Reimer 1994; Sanyal et al. 1995). The change in surface ocean carbonate ion is very different in these two scenarios because the ratio of carbonate ion increase to $\mathrm{pCO}_{2}$ decrease depends on the surface ocean alkalinity: $\mathrm{CO}_{2}$ change (Fig. 1). A smaller change is associated with the drawdown of dissolved carbon dioxide under conditions of unchanging alkalinity, as would be the case if the biological pump were strengthened solely through an increase in the Redfield ratio of phytoplankton, without any calcite compensation (Broecker 1982b; Broecker and Henderson 1998). In this case, a $40\left(\right.$ at $10^{\circ} \mathrm{C}$ ) to 50 (at $\left.25^{\circ} \mathrm{C}\right) \mu \mathrm{mol} / \mathrm{kg}$ surface water carbonate ion increase equates to a $\mathrm{pCO}_{2}$ of $200 \mathrm{ppmV}$. However, if the same $\mathrm{pCO}_{2}$ level is achieved by the addition of calcium carbonate to seawater, as in the coral reef hypothesis, carbonate ion increases by $80\left(\right.$ at $10^{\circ} \mathrm{C}$ ) to 110 (at $\left.25^{\circ} \mathrm{C}\right) \mu \mathrm{mol} / \mathrm{kg}$ (Fig. 1a, b). The change in carbonate ion required to achieve a specific $\mathrm{pCO}_{2}$ level is smaller in cold waters because they contain less carbonate ion and therefore require smaller fractional changes to match the glacial $\mathrm{pCO}_{2}$ reduction.

The calculated changes in surface water carbonate ion for the two scenarios are converted to $\delta^{13} \mathrm{C}$ anomalies using the experimental response for G. bulloides, a sub-polar species, for the $10^{\circ} \mathrm{C}$ calculation and the response for $O$. universa, a sub-tropical species, for the $25^{\circ} \mathrm{C}$ calculation (Fig. $1 \mathrm{c}, \mathrm{d})$. Predicted anomalies in shell $\delta^{13} \mathrm{C}$ due to increased glacial carbonate ion range between -0.3 and $-0.9 \%$, with the largest anomalies predicted for G. bulloides under the conditions of $\mathrm{CaCO}_{3}$ addition. In general, the predicted anomalies in shell $\delta^{13} \mathrm{C}$ for the $\mathrm{CaCO}_{3}$ addition scenario are twice that of the anomalies predicted for the $\mathrm{CO}_{2}$ extraction scenario. It should be noted that the contrast in seawater $\mathrm{pH}$ increase for the two scenarios is smaller: $0.11 \mathrm{pH}$ units for the $\mathrm{CO}_{2}$ drawdown sce- nario versus 0.15 for the $\mathrm{CaCO}_{3}$ addition scenario. Therefore, if $\mathrm{pH}$ controls the isotopic deviations in the foraminifer shells, we would predict a less dramatic $\delta^{13} \mathrm{C}$ anomaly difference for the two scenarios.

We have also generated general circulation model simulations of surface water carbonate ion concentrations for the interglacial ocean (Fig. 2a) and two glacial simulations with lowered atmospheric $\mathrm{pCO}_{2}$ (Fig. 2b, c) (Archer et al. in review). The first glacial simulation increases oceanic $\mathrm{NO}_{3}{ }_{3}^{-}$ by $50 \%$ (Fig. $2 \mathrm{~b}$ ) and assumes that plankton productivity increases in proportion to the nitrate increase (Broecker and Henderson 1998). There is no $\mathrm{CaCO}_{3}$ compensation in this simulation, which is analogous to the $\mathrm{CO}_{2}$ extraction scenario discussed above. The second glacial simulation invokes a doubling of ocean $\mathrm{H}_{4} \mathrm{SiO}_{4}$ (Fig. 2c), which perturbs calcite burial in such a way that oceanic alkalinity increases through $\mathrm{CaCO}_{3}$ compensation (Archer and Maier-Reimer 1994). This simulation is analogous to the $\mathrm{CaCO}_{3}$ addition scenario discussed above. As predicted from the calculations above, the change in surface water carbonate ion generated by the doubling of oceanic $\mathrm{H}_{4} \mathrm{SiO}_{4}$ $\left(\mathrm{CaCO}_{3}\right.$ addition) is much larger than for a $50 \%$ nitrate increase $\left(\mathrm{CO}_{2}\right.$ extraction). In line with these simulations, the predicted negative anomalies in foraminifer shell $\delta^{13} \mathrm{C}$ due to the carbonate ion effect would be consequently greater for $\mathrm{pCO}_{2}$ reduction achieved via ocean alkalinity increase as opposed to a stronger biological pump.

\section{Predicted $\boldsymbol{\delta}^{13} \mathrm{C}$ Anomalies Compared to Downcore Records}

High resolution isotopic data from core RC11-83 in the sub-polar South Atlantic provides a useful basis of comparison with the $\delta^{13} \mathrm{C}$ anomalies predicted for G. bulloides (Charles et al. 1996). Carbon isotope anomalies due to the influence of changing surface water carbonate ion concentration are computed for the last $200 \mathrm{kyrs}$ based on the Vostok $\mathrm{pCO}_{2}$ record and the assumption that surface waters were in equilibrium with the atmosphere (Fig. $3)$. Our calculations demonstrate that $\delta^{13} \mathrm{C}$ anomalies, when computed for the condition of $\mathrm{CaCO}_{3}$ addition (i.e. maximum carbonate anomaly), give 
$\mathrm{SST}=10^{\circ} \mathrm{C}:$ G. bulloides response
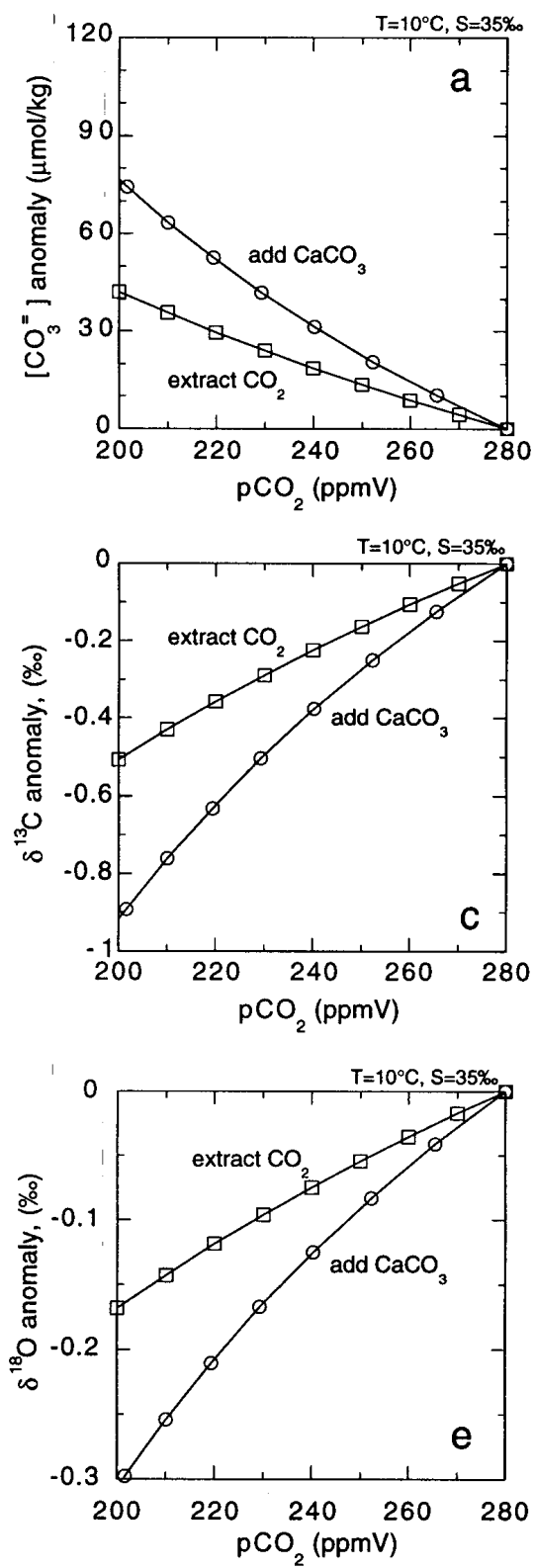

$\mathrm{SST}=25^{\circ} \mathrm{C}:$ O. universa response
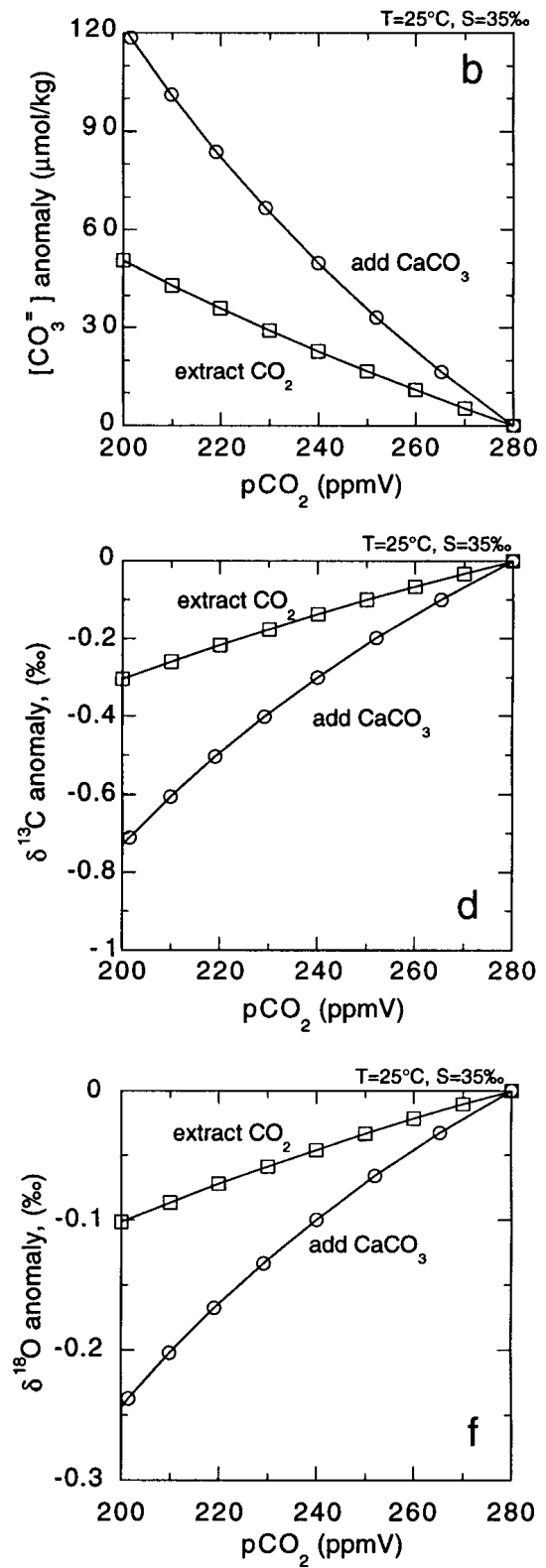

Fig. 1. Change in surface water carbonate ion at $10^{\circ}$ and $25^{\circ} \mathrm{C}$ for equilibrium with specific $\mathrm{pCO}_{2}$ levels relative to a baseline $\mathrm{pCO}_{2}$ level of $280 \mathrm{ppmV}$. The change in carbonate ion required to achieve a specific $\mathrm{pCO}_{2}$ level is smaller in cold waters because polar waters contain the lowest carbonate ion levels and therefore require smaller fractional changes to match the glacial $\mathrm{pCO}_{2}$ reduction. (a), (b) Carbonate ion levels are calculated for two $\mathrm{pCO}_{2}$ reduction scenarios: addition of $\mathrm{CaCO}_{3}$ (i.e. "Coral Reef" hypothesis), and extraction of $\mathrm{CO}_{2}$ (i.e. "Biological Pump" hypothesis). The change in surface ocean carbonate ion is larger for $\mathrm{CaCO}_{3}$ addition because $1 \mathrm{~mol}$ of $\mathrm{CO}_{2}$ is added for every 2 equivalents of alkalinity. (c), (d) Carbon isotope anomalies calculated from the carbonate ion anomalies and the experimental response for G. bulloides, a sub-polar species, and O. universa, a sub-tropical species. (e), (f) Oxygen isotope anomalies calculated from the carbonate ion anomalies and the experimental responses. A- $0.21 \%$ anomaly in $\delta^{18} \mathrm{O}$ is approximately equivalent to a $-1^{\circ} \mathrm{C}$ anomaly in sea surface temperature. 


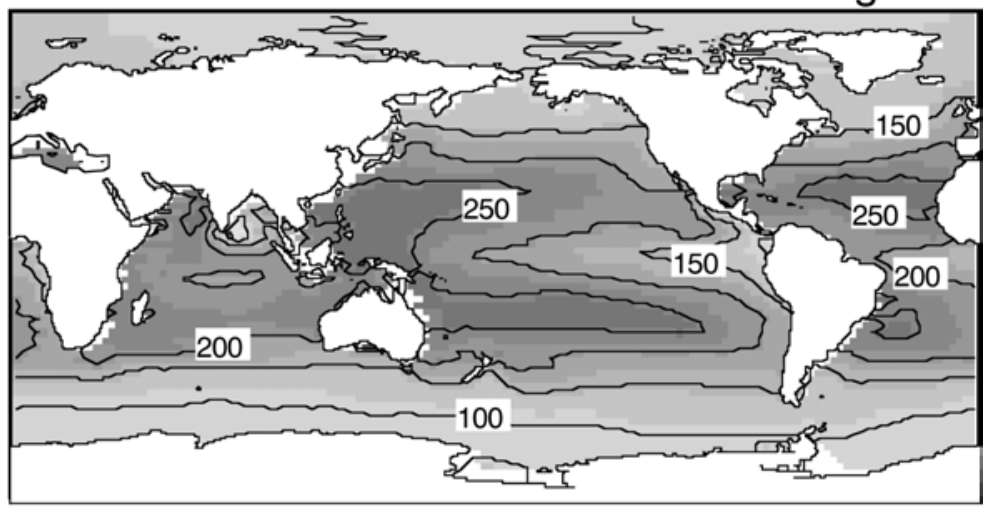

$b$

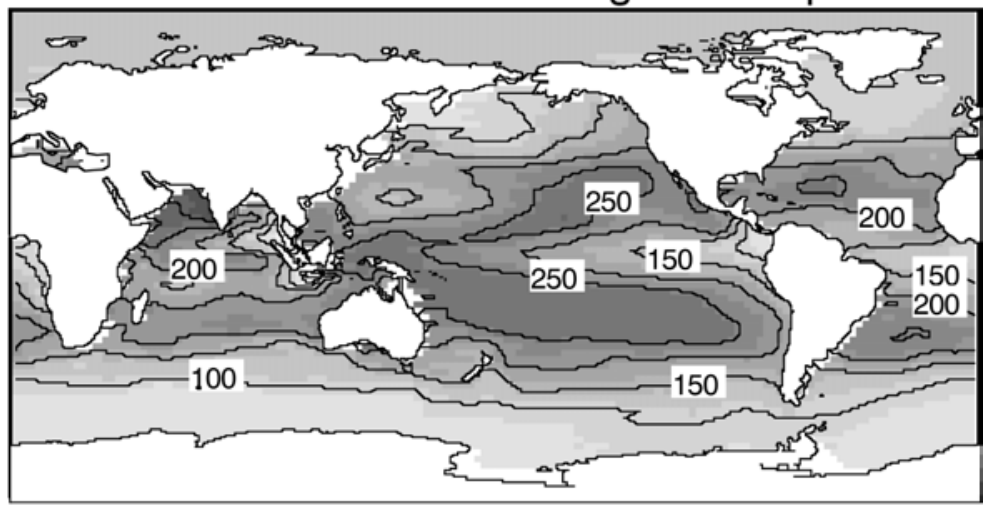

$c$

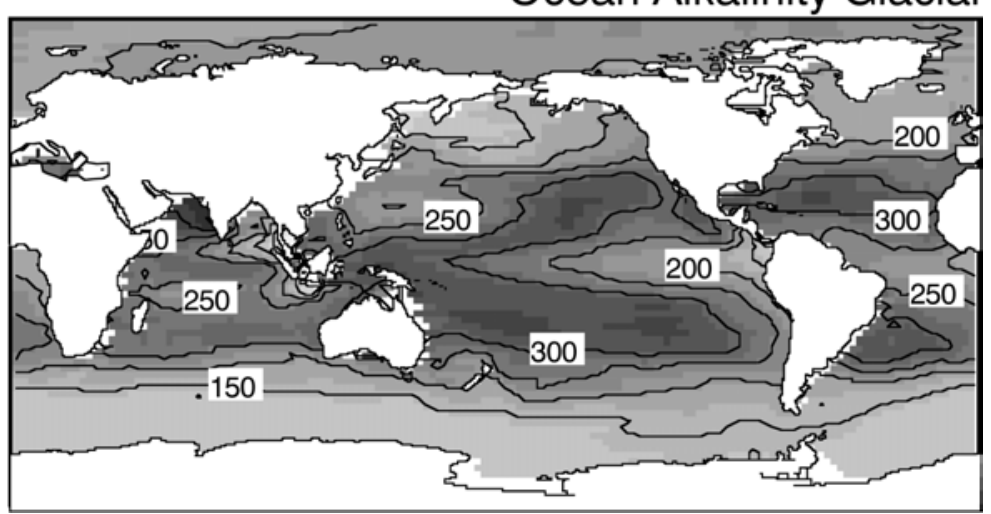

Fig. 2. General Circulation Model (GCM) simulations of surface water carbonate ion concentrations for the interglacial ocean (a) and two glacial simulations with lowered atmospheric $\mathrm{pCO}_{2}$ (b and $\mathbf{c}$ ). The GCM simulations are based on a model described in Archer et al. (in review) and include estimates of glacial flow fields, the effects of terrestrial carbon addition, temperature changes, glacial atmospheric iron deposition and iron limitation on productivity. The first glacial simulation increases oceanic $\mathrm{NO}_{3}^{-}$by $50 \%$ (Fig. 2b) and assumes that plankton productivity increases in proportion to the nitrate increase (Broecker and Henderson 1998). There is no $\mathrm{CaCO}_{3}$ compensation in this simulation. The second glacial simulation invokes a doubling of ocean $\mathrm{H}_{4} \mathrm{SiO}_{4}$ (Fig. 2c), which perturbs calcite burial in such a way that oceanic alkalinity increases through $\mathrm{CaCO}_{3}$ compensation (Archer and Maier-Reimer 1994). This simulation is analogous to the $\mathrm{CaCO}_{3}$ addition scenario discussed above. The change in surface water carbonate ion generated by the doubling of oceanic $\mathrm{H}_{4} \mathrm{SiO}_{4}\left(\mathrm{CaCO}_{3}\right.$ addition $)$ is much larger than for a $50 \%$ nitrate increase $\left(\mathrm{CO}_{2} \mathrm{ex}\right.$ traction). In line with these simulations, the predicted negative anomalies in foraminifer shell $\delta^{13} \mathrm{C}$ due to the carbonate ion effect would be consequently greater for $\mathrm{pCO}_{2}$ reduction achieved via ocean alkalinity increase as opposed to a stronger biological pump. rise to a reasonably close match with the observed G. bulloides $\delta^{13} \mathrm{C}$ record (Fig. 3a). The temporal match with the $N$. pachyderma record is also good, but the magnitude of the observed $\delta^{13} \mathrm{C}$ shifts is about $0.5 \%$ greater than the $\delta^{13} \mathrm{C}$ anomalies calculated using the G. bulloides response (Fig. 3b). The similarity of the $\delta^{13} \mathrm{C}$ records of $G$. bulloides and $N$. pachyderma coupled with the difference in the absolute magnitudes of the glacial-intergla- cial shifts could be explained if N. pachyderma shells have a larger response to changes in carbonate ion. Regardless, the carbonate ion effect provides a novel explanation for the large, negative swings in planktic $\delta^{13} \mathrm{C}$ observed in the glacial sections of Southern Ocean cores.

Comparison of warm water $\delta^{13} \mathrm{C}$ anomalies with tropical planktic $\delta^{13} \mathrm{C}$ records is hampered by the availability of very limited paleoceanographic 

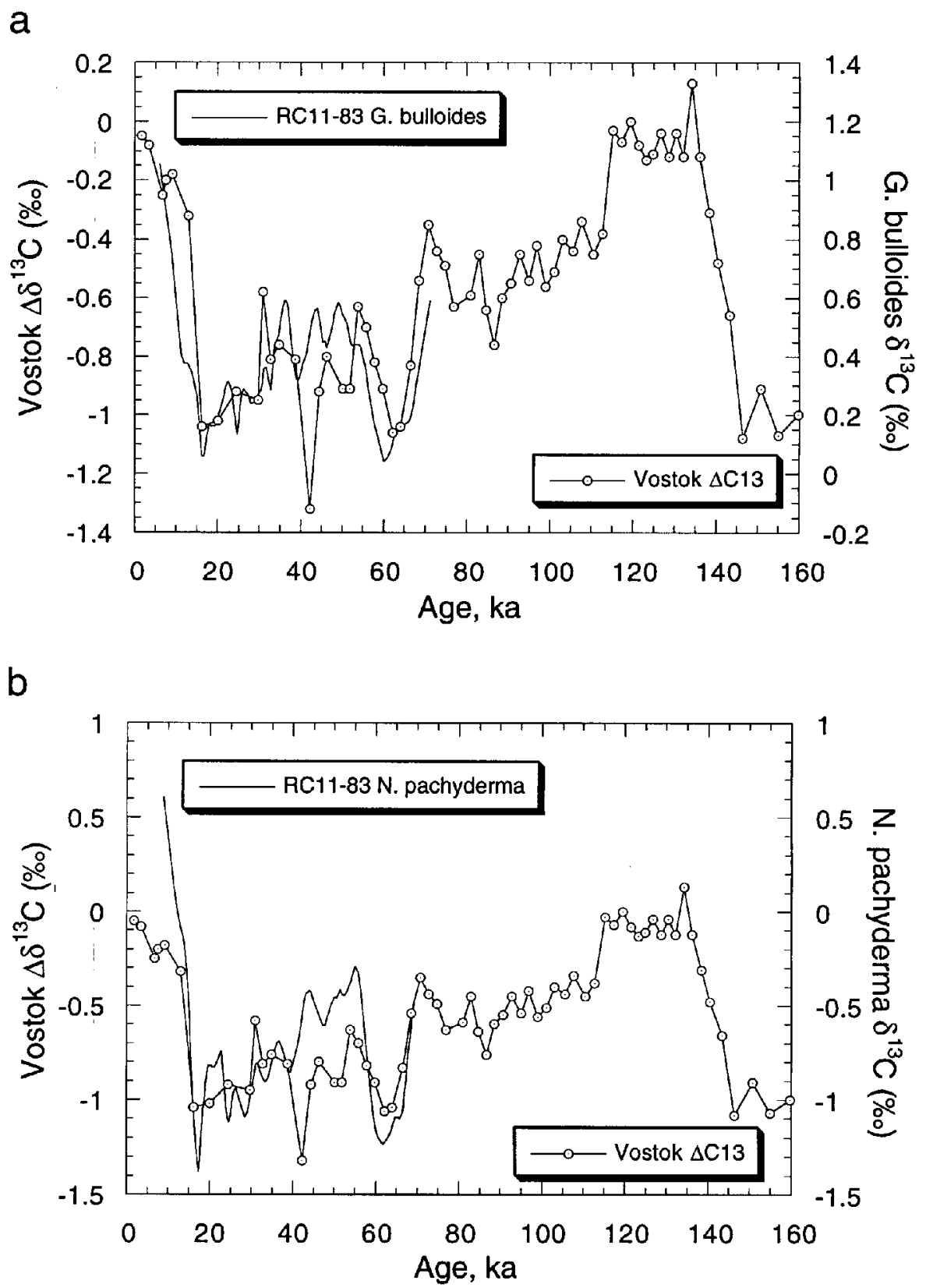

Fig. 3. Comparison of $\delta^{13} \mathrm{C}$ anomalies computed from the Vostok $\mathrm{pCO}_{2}$ record with planktic $\delta^{13} \mathrm{C}$ records from South Atlantic core RC11-83 $\left(42^{\circ} \mathrm{S} ; 10^{\circ} \mathrm{E} ; 4718 \mathrm{~m}\right)$ (Charles et al. 1996). Carbonate ion anomalies are computed from the Vostok $\mathrm{pCO}_{2}$ record relative to a baseline $\mathrm{pCO}_{2}$ level of $280 \mathrm{ppmV}$, assuming $\mathrm{pCO}_{2}$ reductions were attained by $\mathrm{CaCO}_{3}$ addition. The calculations assume surface water-atmosphere equilibrium and a sea surface temperature of $10^{\circ} \mathrm{C}$. Vostok $\Delta \delta^{13} \mathrm{C}$ values are computed from the carbonate anomalies using the experimental response for $G$. bulloides. Note that the minimum at $42 \mathrm{kyr}$ derives from a $\mathrm{pCO}_{2}$ minimum in the original Vostok record that is less pronounced in later records (Jouzel et al. 1993). The isotope data from RC11-83 has been smoothed by a locally weighted least squared error method to facilitate comparison. For both plots the Vostok and RC11-83 $\delta^{13} \mathrm{C}$ scales are matched in magnitude. (a) The negative shift in G. bulloides $\delta^{13} \mathrm{C}$ matches the magnitude of the calculated $\delta^{13} \mathrm{C}$ values computed from the Vostok record. (b) The negative shift in $N$. pachyderma $\delta^{13} \mathrm{C}$ exceeds the magnitude of the Vostock $\Delta \delta^{13} \mathrm{C}$ values calculated using the response for G. bulloides. 
data for $O$. universa. Planktic $\delta^{13} \mathrm{C}$ records from two tropical surface-dwelling species indicate typical interglacial to glacial differences of only -0.2 to $-0.3 \%$ for Globigerinoides sacculifer, whereas Globigerinoides ruber records indicate shifts of $-0.3 \%$ up to as large as $-0.8 \%$ (Shackleton 1977; Curry and Crowley 1987; Oppo and Fairbanks 1989; Mix 1992; Shackleton et al. 1992; Struck et al. 1993; Linsley and Dunbar 1994; Stott and Tang 1996). The calculated magnitude of the carbonate ion effect in warm waters, -0.3 to $-0.7 \%$ o (Fig. 2d), falls within the range of observed $\delta^{13} \mathrm{C}$ differences. But in most of the planktic records from warm waters the minimum in $\delta^{13} \mathrm{C}$ occurs on the glacial termination, when atmospheric $\mathrm{pCO}_{2}$ and, by extension, surface water carbonate ion levels were already well on their return to Holocene values (Sowers and Bender 1995). Another important factor that requires explanation is that the most positive shell $\delta^{13} \mathrm{C}$ values are often found in the early Holocene rather than at the core-top. The difference in timing between the tropical/sub-tropical $\delta^{13} \mathrm{C}$ records and the predicted change in surface ocean carbonate ion appears to preclude carbonate ion concentrations as the principal control on shell $\delta^{13} \mathrm{C}$. However, if carbonate ion is an important influence, the paradox of two surface-dwelling tropical species recording such different $\delta^{13} \mathrm{C}$ shifts could be explained by a greater carbonate ion response for G. ruber. This hypothesis has recently been confirmed by culturing experiments (Bijma et al. 1998).

\section{Carbonate in the Deep Ocean}

Because the deep ocean is not in direct contact with the atmosphere, there is no single constraint that can be imposed on the carbonate chemistry of glacial bottom waters. In addition, it is not known if carbonate ion concentrations influence the stable isotopic composition of benthic shells. Proposed scenarios for the glacial abyss range from nearly unchanged carbonate ion, which would match observations of only small glacial-interglacial changes in the lysocline (oceanic depth below which sedimentary calcite dissolves), to a near doubling of deep water carbonate ion concentrations, implied by proxy pH data (Sanyal et al. 1995). Of the two hypotheses for reduced glacial $\mathrm{pCO}_{2}$ considered here, a strengthened biological pump would lead to negligible changes in abyssal carbonate ion, whereas any of the $\mathrm{CaCO}_{3}$ cycling changes would result in a large increase in abyssal carbonate ion (Archer and Maier-Reimer 1994).

If there is no carbonate ion influence on benthic foraminifera, or if deep water carbonate ion remained constant, correcting solely for the effect of higher glacial carbonate ion on planktic shells would make planktic $\delta^{13} \mathrm{C}$ values more positive and therefore increase the true glacial planktic-benthic $\delta^{13} \mathrm{C}$ difference $\left(\Delta \delta^{13} \mathrm{C}\right)$. A greater surface-deep $\delta^{13} \mathrm{C}$ difference equates to a stronger glacial biological pump. A $0.1 \%$ increase in $\Delta \delta^{13} \mathrm{C}$ translates to an approximate $10 \mathrm{ppmV}$ drop in $\mathrm{pCO}_{2}$, so a $0.4 \%$ correction on planktic $\delta^{13} \mathrm{C}$ due to higher carbonate ion combined with the observed $0.4 \%$ average glacial increase in $\Delta \delta^{13} \mathrm{C}$ would be sufficient to explain the entire $80 \mathrm{ppmV}$ glacial-interglacial $\mathrm{pCO}_{2}$ difference (Shackleton et al. 1983a; Shackleton and Pisias 1985; Curry and Crowley 1987; Shackleton et al. 1992).

The alternative scenario is that carbonate ion concentration does influence benthic shell $\delta^{13} \mathrm{C}$. In that case, the negative shift in benthic $\delta^{13} \mathrm{C}$ during glacial episodes would be consistent with a wholeocean increase in carbonate ion and $\mathrm{pH}$, as expected for a $\mathrm{pCO}_{2}$ drawdown due to changes in $\mathrm{CaCO}_{3}$ cycling (Archer and Maier-Reimer 1994; Sanyal et al. 1995). If the benthic response is similar to planktics (i.e. $\sim-0.01 \%$ per $\mu \mathrm{mol} / \mathrm{kg}$ ), the $-0.4 \%$ observed change in glacial benthic $\delta^{13} \mathrm{C}$ (Curry et al. 1988) would be equivalent to a 40 $\mu \mathrm{mol} / \mathrm{kg}$ increase in abyssal carbonate ion.

\section{Influence of Carbonate Ion on Glacial Oxygen Isotope Ratios}

Oxygen isotopic ratios in planktic foraminifera are an important constraint on surface ocean cooling during the LGM. Isotopic paleotemperatures appear to be consistent with CLIMAP reconstructions, which suggest that tropical surface temperatures did not cool by more than $2^{\circ} \mathrm{C}$ during the LGM (Broecker 1986; Stott and Tang 1996). However, the extent of agreement depends on the actual 
glacial to interglacial change in seawater $\delta^{18} \mathrm{O}$, which might have been smaller than previously thought (Schrag et al. 1996). Other marine SST proxies (e.g. coral $\mathrm{Sr} / \mathrm{Ca}$ ) as well as terrestrial indicators (e.g. snow-line and ice core $\delta^{18} \mathrm{O}$ ) suggest tropical cooling of $4-6^{\circ} \mathrm{C}$ at the LGM (Guilderson et al. 1994; Thompson et al. 1995). Experimental data demonstrates that shell $\delta^{18} \mathrm{O}$ drops -0.002 and $-0.004 \%$ per $\mu \mathrm{mol} / \mathrm{kg}$ carbonate ion increase for O. universa and G. bulloides, respectively (Spero et al. 1997).

Anomalies in $\delta^{18} \mathrm{O}$ computed for an $80 \mathrm{ppmV}$ $\mathrm{pCO}_{2}$ reduction range from -0.1 to $-0.3 \%$, equivalent to an SST anomaly of approximately -0.5 to $1.5^{\circ} \mathrm{C}$ (Fig. 2e, f). These anomalies in shell $\delta^{18} \mathrm{O}$ are negative deviations from apparent equilibrium which translate into overestimates of paleotemperature during periods of low $\mathrm{pCO}_{2}$. For example, for an observed glacial-interglacial planktic $\delta^{18} \mathrm{O}$ difference of $1.5 \%$ in tropical cores (Broecker 1986; Shackleton et al. 1992; Linsley and Dunbar 1994; Thunell et al. 1994), correcting for the influence of higher carbonate ion on glacial shells could increase the $\delta^{18} \mathrm{O}$ difference to $1.7 \%$. Assuming the more recent $1 \%$ estimate of the glacial - interglacial ice volume effect (Fairbanks 1989; Schrag et al. 1996), the residual $0.7 \%$ is compatible with tropical cooling of up to $3.5^{\circ} \mathrm{C}$. The influence of carbonate ion on shell $\delta^{18} \mathrm{O}$ also influences paleo-salinity estimates based on G. bulloides $\delta^{18} \mathrm{O}$ (Duplessy et al. 1991). A $0.3 \%$ correction on $\delta^{18} \mathrm{O}$ would reduce calculated LGM salinity anomalies by about $0.6 \mathrm{psu}$.

\section{Conclusions}

Our analysis of the influence of increased carbonate ion on glacial isotopic distributions suggests potential solutions to some intractable paleoceanographic problems, but raises fundamental questions as well. The carbonate ion effect can explain why the amplitude of Southern Ocean G. bulloides $\delta^{13} \mathrm{C}$ records is larger than observed in other planktic records. However, our analysis does not resolve the extent to which planktic $\delta^{13} \mathrm{C}$ records reflect changes in the strength of the biological pump (Shackleton et al. 1983a; Shackleton and Pisias 1985; Curry and Crowley 1987; Shackleton et al. 1992). If planktics alone require a correction for higher glacial carbonate ion, the actual surface - deep $\delta^{13} \mathrm{C}$ difference during glacial episodes was significantly larger $(\sim 0.4 \%$ ) than calculated from the foraminiferal shell $\delta^{13} \mathrm{C}$ differences. If benthic shell $\delta^{13} \mathrm{C}$ is also affected by carbonate ion concentration, some or all of the negative carbon isotope shift during glacial episodes is likely to be due to a whole-ocean carbonate ion increase. This attribution reduces the actual mean ocean $\delta^{13} \mathrm{C}$ shift and therefore diminishes the inferred amount of terrestrial carbon transferred to the ocean during the LGM. This change further enlarges the difference between pollen-based and ocean $\delta^{13} \mathrm{C}$-based estimates of the amount of carbon transferred from the terrestrial biosphere to the ocean during glacial episodes (Shackleton 1977; Crowley 1995). Because the carbonate ion effect appears to be a major factor influencing the foraminiferal isotope record, calibration of the response in each of the major paleoceanographic planktic and benthic species is a necessary next step towards fully understanding and utilizing the oceanic isotopic record.

\section{Acknowledgments}

The senior author would like to thank the Department of Geophysical Sciences, University of Chicago, for a Visiting Professorship, support, and facilities, while undertaking this research. Thanks go to Alan Mix, Brad Linsley, Chris Charles, Tom Crowley, Lloyd Keigwin and Michael Sarnthein for sharing isotope data and to Jim Kennett and Nick Shackleton for comments on the ms. Reviews by W. Berger and an anonymous reviewer improved the manuscript. This research was supported by the US National Science Foundation (DWL and HJS) and by the Deutsche Forschungsgemeinschaft (Sonderforschungsbereich 261 at Bremen University, Contribution no. 204) and the Program for the Advancement of Special Research Projects at the Alfred Wegener Institute, Germany (JB). 


\section{References}

Archer D, Maier-Reimer E (1994) Effect of deep-sea sedimentary calcite preservation on atmospheric $\mathrm{CO}_{2}$ concentration. Nature 367: 260-263

Archer D, Winguth A, Lea DW, Mahowald N What caused the glacial/interglacial atmospheric $\mathrm{PCO}_{2}$ cycles? Reviews of Geophysics, in review

Barnola JM, Raynaud D, Korotkevich YS, Lorius C (1987) Vostok ice core provides 160,000-year record of atmospheric $\mathrm{CO}_{2}$. Nature 329: 408-414

Berger WH (1982) Increase of carbon dioxide in the atmosphere during deglaciation: The coral reef hypothesis. Naturwissenschaften 69: 87-88

Berger WH, Killingley JS, Vincent E (1978) Stable isotopes in deep-sea carbonates: Box core ERDC-92, west equatorial Pacific. Oceanol Acta 1: 203-216

Bijma J, Spero HJ, Lea DW (1998) Oceanic carbonate chemistry and foraminiferal isotopes: new laboratory results. 6th International Conference on Paleoceanography, Program and Abstracts, 78

Boyle EA (1988) The role of vertical chemical fractionation in controlling late Quaternary atmospheric carbon dioxide. J Geophys Res 93: 15, $701-15,715$

Boyle EA (1992) Cadmium and $\delta^{13} \mathrm{C}$ paleochemical ocean distributions during the stage 2 glacial maximum. Annu Rev Earth Planet Sci 20: 245-287

Boyle EA, Keigwin LD (1982) Deep circulation of the North Atlantic over the last 200,000 years: Geochemical evidence. Science 218: 784-787

Boyle EA, Keigwin LD (1985/1986) Comparison of Atlantic and Pacific paleochemical records for the last 215,000 years: changes in deep ocean circulation and chemical inventories. Earth Planet Sci Lett 76: 135-150

Broecker WS (1982a) Glacial to interglacial changes in ocean chemistry. Progr Oceanogr 11: 151-197

Broecker WS (1982b) Ocean chemistry during glacial time. Geochim Cosmochim Acta 46: 1689-1705

Broecker WS (1986) Oxygen isotope constraints on surface ocean temperatures. Quat Res 26: 121-134

Broecker WS, Henderson GM (1998) The sequence of events surrounding Termination II and their implications for the cause of glacial-interglacial $\mathrm{CO}_{2}$ changes. Paleoceanography 13: 352-364

Broecker WS, Peng T-H (1993) What caused the glacial to interglacial $\mathrm{CO}_{2}$ change? In: Heimann $\mathrm{M}$ (ed) The Global Carbon Cycle. Springer, Berlin Heidelberg New York, pp 95-115

Charles CD, Fairbanks RG (1990) Glacial to interglacial changes in the isotopic gradients of Southern Ocean surface water. In: Bleil U, Thiede J (eds) Geological History of the Polar Oceans: Arctic versus Antarctic. Kluwer, Dordrecht, pp 519-538

Charles CD, Wright JD, Fairbanks RG (1993) Thermodynamic influences on the marine carbon isotope record. Paleoceanography 8: 691-697

Charles CD, Lynch-Stieglitz J, Ninnemann U, Fairbanks R (1996) Climate connections between the hemisphere revealed by deep sea sediment core ice core correlations. Earth Planet Sci Lett 142: 19-27

Crowley TJ (1995) Ice age terrestrial carbon changes revisited. Global Biogeochem Cycles 9: 377-389

Curry WB, Crowley TJ (1987) The $\delta^{13} \mathrm{C}$ of equatorial Atlantic surface waters: implications for ice age $\mathrm{pCO}_{2}$ levels. Paleoceanography 2: 489-517

Curry WB, Lohmann GP (1982) Carbon isotopic changes in benthic foraminifera from the Western South Atlantic: reconstruction of glacial Abyssal circulation patterns. Quat Res 18: 218-235

Curry WB, Duplessy J-C, Labeyrie LD, Shackleton NJ (1988) Changes in the distribution of $\delta^{13} \mathrm{C}$ of deep water $\mathrm{\Sigma CO}_{2}$ between the last glaciation and the Holocene. Paleoceanography 3: 317-342

Duplessy J-C, Shackleton NJ, Fairbanks RG, Labeyrie L, Oppo D, Kallel N (1988) Deepwater source variations during the last climatic cycle and their impact on the global deepwater circulation. Paleoceanography 3: 343-360

Duplessy J-C, Labeyrie L, Juillet-Leclerc A, Maitre F, Duprat J, Sarnthein M (1991) Surface salinity reconstruction of the North Atlantic Ocean during the last glacial maximum. Oceanol Acta 14: 311-324

Fairbanks RG (1989) A 17,000-year glacio-eustatic sea level record: influence of glacial melting rates on the Younger Dryas event and deep-ocean circulation. Nature 342: 637-642

Guilderson TP, Fairbanks RG, Rubenstone JL (1994) Tropical temperature variations since 20,000 years ago: Modulating interhemispheric climate changes. Science 263: 663-665

Jouzel J, Barkov NI, Barnola JM, Bender M, Chappeilaz J, Genthon C, Kotlyakov VM, Lipenkov V, Lorius C, Petit JR, Raynaud D, Raisbeck G, Ritz C, Sowers T, Stievenard M, Yiou F, Yiou P (1993) Extending the Vostok ice-core record of palaeoclimate to the penultimate glacial period. Nature 364: 407-412

Labeyrie LD, Duplessy JC (1985) Changes in the oceanic ${ }^{13} \mathrm{C} /{ }^{12} \mathrm{C}$ ratio during the last 140000 years: high latitude surface water records. Palaeogeogr Palaeoclimatol Palaeoecol 50: 217-240 
Lea DW (1995) A trace metal perspective on the evolution of Antarctic Circumpolar Deepwater chemistry. Paleoceanography 10: 733-747

Linsley BK, Dunbar RB (1994) The late pleistocene history of surface water $\delta^{13} \mathrm{C}$ in the Sulu Sea: possible relationship to Pacific deepwater $\delta^{13} \mathrm{C}$ changes. Paleoceanography 9: 317-340

Mackensen A, Hubberten H-W, Bickert T, Fischer G, Fütterer DK (1993) The $\delta^{13} \mathrm{C}$ in benthic foraminiferal tests of Fontbotia wuellerstorfi (Schwager) relative to the $\delta^{13} \mathrm{C}$ of dissolved inorganic carbon in Southern Ocean deep water: Implications for glacial ocean circulation models. Paleoceanography 8: 587-610

McCorkle DC, Keigwin LD, Corliss BH, Emerson SR (1990) The influence of microhabitats on the carbon isotopic composition of deepsea benthic foraminfiera. Paleoceanography 5: 161-185

Mix AC (1992) The marine oxygen isotope record: constraints on timing and extent of ice-growth events (120-65 ka). In: Clark PU, Lea PD (eds) The Last Interglacial Transition in North America. Geol Soc Amer Spec Paper, Boulder, Colorado, pp 19-30

Oppo DW, Fairbanks RG (1989) Carbon isotope composition of tropical surface water during the past 22,000 years. Paleoceanography 4: 333-352

Sanyal A, Hemming NG, Hanson GN, Broecker WS (1995) Evidence for a higher $\mathrm{pH}$ in the glacial ocean from boron isotopes in foraminifera. Nature 373: 234-236

Schrag DP, Hampt G, Murray DW (1996) Pore Fluid Constraints on the Temperature and Oxygen Isotopic Composition of the Glacial Ocean. Science 272: 1930-1932

Shackleton $\mathrm{NJ}(1977){ }^{13} \mathrm{C}$ in Uvigerina: Tropical rainforest history and the equatorial Pacific carbonate dissolution cycles. In: Anderson N, Malahof A (eds) Fate of Fossil Fuel $\mathrm{CO}_{2}$ in the Oceans. Plenum, New York, pp 401-427

Shackleton NJ, Pisias NG (1985) Atmospheric carbon dioxide, orbital forcing, and climate. In: Sundquist ET, Broecker WS (eds) The Carbon Cycle and Atmospheric $\mathrm{CO}_{2}$ : Natural Variations Archean to Present. AGU, Washington DC, pp 303-317
Shackleton NJ, Hall MA, Line J, Cang S (1983a) Carbon isotope data in core V19-30 confirm reduced carbon dioxide concentration in the ice age atmosphere. Nature 306: 319-322

Shackleton NJ, Imbrie J, Hall MA (1983b) Oxygen and carbon isotope record of East Pacific core V19-30: implications for the formation of deep water in the last Pleistocene North Atlantic. Earth Planet Sci Lett 65:233-244

Shackleton NJ, Le J, Mix A, Hall MA (1992) Carbon isotope records from Pacific surface waters and atmospheric carbon dioxide. Quat Sci Rev 11: 387-400

Sowers T, Bender M (1995) Climate records covering the last deglaciation. Science 269: 210-214

Spero HJ, Lea DW (1996) Experimental determination of stable isotopic variability in Globigerina bulloides: implications for paleoceanographic reconstructions. Mar Micropaleontol 28: 231-246

Spero HJ, Williams DF (1988) Extracting environmental information from planktonic foraminiferal $\delta^{13} \mathrm{C}$ data. Nature 335: 717-719

Spero HJ, Bijma J, Lea DW, Bemis B (1997) Effect of seawater carbonate chemistry on planktonic foraminiferal carbon and oxygen isotope values. Nature 390: 497-500

Stott LD, Tang CM (1996) Reassessment of foraminiferalbased tropical sea surface $\delta^{18} \mathrm{O}$ paleotemperatures. Paleoceanography 11:37-56

Struck U, Sarnthein M, Westerhausen L, Barnola JM, Raynaud D (1993) Ocean-atmosphere carbon exchange: impact of the "biological pump" in the Atlantic equatorial upwelling belt over the last 330,000 years. Palaeogeogr Palaeoclimatol Palaeoecol 103: 41-56

Thompson LG, Mosley-Thompson E, Davis ME, Lin PN, Henderson KA, Cole-Dia J, Bolzan JF, Liu K-b (1995) Late Glacial stage and Holocene tropical ice core records from Huascarán, Peru. Science 269: 46-50

Thunell R, Anderson D, Gellar D, Miao Q (1994) Seasurface temperature estimates for the Tropical Western Pacific during the last glaciation and their implications for the Pacific Warm Pool. Quat Res 41: 255-264 